\title{
Discourse Analysis on the Representation of Poverty in Southern Nias Culture
}

\author{
Juang Solala Laiya \\ Department of Development Studies \\ University of Sumatra Utara \\ Medan, Indonesia \\ Email: juang.solala@gmail.com
}

\begin{abstract}
This paper is part of a more comprehensive study addressing the inequality in interpretation of poverty meanings more inclined to global narratives of poverty, constructed by dominant actors, like academic institutions, donor agencies, governments, etc., who unilaterally claim positions as regimes of truth and at the same time marginalize local narratives derived from the perspective of the poor in seeing themselves and the conditions they are experiencing. Given limited space for discussion, the writers will focus more on describing a local narrative on poverty, derived from the textual comparison between the discourses of poverty in Nias language with the representation of poverty discourse in some social practices of traditional society of South Nias. Through this inter-textual approach, the writer hopes to unite some traditional cultural pieces of Southern Nias society scattered in various social practices, to make an interpretation to explain what is meant to be poor in traditional perspective of Southern Nias society.
\end{abstract}

Keywords: discourse; poverty; representation; culture; southern nias.

\section{INTRODUCTION}

The inspiration of this research stems from data published by Badan Pusat Statistik Sumatra Utara (2016), which states the highest percentage of poor people in North Sumatra is located in the Nias Islands. On the first position is North Nias Regency (31\%), followed by Gunung Sitoli (31\%), West Nias (30\%) and South Nias (19\%). This information is interesting, because how is it possible for a region that holds various potential resources, including productive land, marine resources, natural beauty, and abundant cultural treasures, categorized as poor areas? This interestingness encourages the writers to do simple experiments. The writer went to Telukdalam port in South Nias which was only 50 meters from the writer's house, then naively asked a fisherman who looked impoverished: are you poor? The fisherman looked surprised and slightly angry. According to him only disabled people who deserve to be called poor.

Although it is still too early to make a conclusion, the spontaneous response of the fisherman makes the writer think the fisherman-as well as the writer-has a personal perspective on poverty. In Gestalt psychology such a personal way of view is called perception, i.e. the process of information processing in a person's cognitive system, where sensory data is used to construct a mental scheme or map of meaning about oneself and the world around him (Bloomer, 1990). As a social being, man does not simply keep his personal perception for himself, but communicates it to others through social practices, including: telling stories, gossiping, arguing, etc. This personal perception are possible to accumulate into a common knowledge which then crystallizes into views shared collectively by a group of individuals living together in a society (Barker, 2005). This is called social perception.

Poverty is sediment from dynamic historical processes that takes place within a long period, with all the continuity and fracture (Sohibuddin \& Achmaliadi, 2010). Thus, as a community group that has undergone a long historical process, of course, the Nias people certainly also have a unique set of collective perceptions about poverty. In the context of the collective perception on poverty, the next question that arises, is whether the percentage of Nias Islands residents who are referred by the Badan Pusat Statistik (BPS) as the poor do consider themselves poor? Even if they consider themselves poor, do they feel poor for reasons like the reasons thought by researchers at BPS? Is the Nias community's idea of poverty the same as the idea of BPS researchers about poverty? So who understands the poverty problem in Nias, the observers or the poor themselves?

These questions are important in light of data published by official institutions, like the Badan Pusat Statistik (BPS), Badan Kependudukan dan Keluarga Berencana Nasional (BKKBN), Badan Perencanaan Nasional (BAPPENAS), and so on; is a standard reference 
for policy planners and apparatus for development in developing intervention programs in poverty alleviation (Sohibuddin \& Achmaliadi, 2010). In the case of poverty in Nias Islands, if the data related to the definition of poverty, the classification of the poor, and the determination of poverty indicators issued by the official institutions are not in accordance with the aspirations and collective views of the Nias community itself about poverty, then this will greatly affect the success rate of poverty alleviation intervention programs in the Nias Islands.

There are currently various approaches that attempt to measure and explain poverty by using generic indicators that rely solely on the objective aspects of poverty, like: housing conditions, type and amount of nutritional intake, income level, asset ownership, etc. (Khomsan et al., 2015). The result is only the accumulation of quantitative definitions of poverty that makes the complexity of the problem of poverty seem reduced to a statistical problem. This condition is complicated by the fact that each approach competes to claim authority as a standard for measuring poverty. Consequently, there has never been a uniform agreement between policy planners and development apparatus-for example between the Ministry of Social Affairs, the Ministry of Public Works, the Ministry of Home Affairs, the Ministry of Public Welfare Coordination, the Ministry for the Acceleration of Development of Underdeveloped Regions-about defining poverty, the classification of the poor, and the determination of poverty indicators (Agusta, 2014).

This condition has made the people of South Nias who became the object of poverty alleviation intervention programs, being oscillated among the various statistical data resulting in various theories and concepts of poverty that became the reference for various policies on poverty. But among these approaches, no single approach has attempted to understand poverty from the view of the poor itself (Tantoro, 2014). Agusta (2014) found that the poor are othered, meaning they are positioned as the other, considered inferior, weak, and uneducated, so it is deemed not to have the competence to voice his opinion of themselves and the conditions they experience. They are only seated as the object of observation of the experts, who unilaterally claim the position of the people who most understand what poverty is. In the view point of political and cultural writerities possessed by dominant institutions, like: BPS, BKKBN, Bappenas or World Bank, the poor opinion of themselves appears irrelevant. The hegemony of the knowledge discourse used by these dominant institutions gives them the legitimacy to claim a position as a truth regime, as well as to remove the subjective experience of the poor itself against poverty, considered merely a trivial bias fact (Agusta, 2014).

This paper is part of a more comprehensive study of the discourse of poverty in the culture of Southern Nias society, which addresses the inequality in interpretation of poverty meanings more inclined to global narratives of poverty, constructed by dominant actors, like academic institutions, donor agencies, governments, etc., who unilaterally claim positions as regimes of truth and at the same time marginalize local narratives derived from the perspective of the poor in seeing themselves and the conditions they are experiencing. Given limited space for discussion, the writers will focus more on describing a local narrative on poverty, derived from the textual comparison between the discourse of poverty in Nias language with the representation of poverty discourse in some social practices of traditional society of South. Through this inter-textual approach, the writer hopes to unite some traditional cultural pieces of Southern Nias society scattered in various social practices, so as to make an interpretation to explain what is meant to be poor in traditional perspective of Southern Nias society.

\section{CONCEPTUAL FRAMEWORK}

Before we go further into the description of the representation of poverty in South Nias culture, the writer needs to explain in advance numerous tools the writer will use: the important concepts and the main assumptions that form the basis for the study of the discourse of poverty in this paper. Here there are five important concepts that the writer will use, namely: reading, perception, representation, discourse, and culture; the writers will describe their notions one by one in the following explanation.

\section{A. Reading}

Reading is the process of discovering the meaning that occurs when the audience interacts or negotiates with the text (Fiske, 2010). This terminology is deliberately chosen, since the reader not only accepts passive meaning of the text but acts actively in interpreting the meaning of the text by bringing aspects of his cultural experience to interact with the codes and marks 
that make up the text. Fiske (2010) found that the meaning of a message is not embedded in the message itself, but is created in the reading process that takes place when the information contained in the message is interpreted as something meaningful by the recipient of the message. This strategy is important because the writer is a member of the Nias community who is undergoing South Nias culture as part of everyday experience. Here, the writer wants to claim cultural legitimacy to interpret the culture of South Nias from the perspective as an insider to Nias culture. By explaining the position, the writers hope the readers of this paper can understand why the writer interprets the text that the writer reads as specific meaning and not others.

\section{B. Perception}

Man perceives himself and the world around him through the process of perception, which is the process of information processing in one's consciousness system, where sensory data (data of sight, hearing, smell, taste and touch) is used to construct mental schemes or maps of meaning about himself and the world around it (Bloomer, 1990). The process of perception makes the result of one's sensing to external reality, not simply entering the internal consciousness (mind), but is filtered through the activity of selecting, organizing, and interpreting the sensing results into meaningful and reasonable images of the world. Thus, perception can be considered a bridge connecting the world of reality and the world of thought. Here, Schiffman and Kanuk (2008) found that humans act and react not on objective reality but on the basis of subjective perceptions. In other words, whatever we call reality is actually the result of editing, which is the result of the selection process, the arrangement, and the interpretation of reality which makes it into something subjective and no longer intact.

\section{Representation}

The fact edited in the process of perception is then saved in our mind as a mental scheme or maps of meaning is composed of a set of signs, symbols, concepts, or ideas, called representation. In general, representations can be defined as a set of signs, symbols, concepts, or ideas, used to link, describe, and reproduce something sensed, imagined, or felt in a particular physical form regarding the activity of forming knowledge (Danesi, 2010). Barker (2004) found that representation is an act of symbolism that reflects something in the world of reality. But here, the representation does not reflect something that exists in external reality simply, but is constitutive of the meanings it refers to. That is, representation does not involve direct correspondence between the sign and the object but creates a representational effect upon reality (Barker, 2004).

\section{Discourse}

Discourse from Foucault's perspective refers to the production of knowledge through language, which gives meaning to material objects and social practices; Foucault regards the external reality as being composed of material objects and social practices that are outside the language, but shown through use of language (Mills, 1997). For Foucault, everything that is known to man is structured within the boundaries, measures, and criteria determined by discursive structures constructed through use of language (Mills, 2003). Through language, discourse brings the world by constructing, defining, categorizing, and producing knowledge objects in a way acceptable to a particular reasoning model, as well as excluding other reasoning models (Mills, 2003).

This means there are many discourses that make up the world of reality. Each discourse contains models of reasoning that represent certain versions in discussing and explaining the reality of the social world. In the interaction of discourse, each discourse seeks to seize dominion over reality, resulting in a discursive struggle, and a winning discourse will temporarily occupy a position of truth regime (Lawlor \& Nale, 2014). That is why in certain discourses, poverty can be interpreted as an economic problem; while in another discourse is interpreted as a way to achieve humility; or even due to God's wrath. Our choice of these meanings will be greatly influenced by which discourse is occupying a position of truth regime.

\section{E. Culture}

Culture is an ambiguous term and does not have a firm definition for every context: culture is a multi-discourse terminology that can be mobilized into various kinds of discourse (Hartley, 2010). In the approach of cultural studies, there is a strong tendency to see culture as the production of meaning or meaningful practices that take place in every layer of social life (Gray, 2003). Culture is the production and circulation of taste, meaning, and consciousness, which becomes the real field for the practices, representations, languages, and habits of a society (Hartley, 2010). Culture deals with questions about social meanings, the various 
ways used to understand the world, so studying culture is tantamount to examining how meaning is produced symbolically (Barker, 2005).

In a broader sense, culture is the whole of knowledge, beliefs, and values humans possess as social beings; consisting of various sets of knowledge models or holistic systems of meaning embodied in historically transmitted symbols (Rohidi, 2000). These systems of meaning are used selectively by their adherents to communicate, to preserve and link knowledge, and as a guide in acting and responding to their environment as they seek to meet their needs (Suparlan, 1984). Thus, culture can be interpreted as: first, a living guide that serves as a blueprint for the lives of the members of the community who follow it; secondly, as a meaning system or cognitive model transmitted through symbolic codes; and thirdly, as an adaptive strategy in developing and preserving life, as well as addressing the environment and the resources contained therein (Rohidi, 2000).

\section{DISCUSSION}

\section{A. GENERAL OVERVIEW OF POVERTY}

Poverty is a concept always in the midst of tension between the various forces in society, competing for domination to frame poverty with certain meanings, as well as trying to get rid of other meanings about poverty. This is for certain a sensible practice in the cultural domain. This paper can also be considered an attempt to draw the meaning of poverty in a certain direction, and at the same time express rejection, or at least reflect on different views on other meanings. Tantoro (2014) found that among the various discourses of poverty, there are two mainstream discourses which have hence become the groundwork for academics and theorists in constructing their arguments: liberal discourse and socialist discourse. Other discourses outside these two discourses are generally a creative compounding of the two discourses, or variations of the theory with assumptions upward to a certain degree, moving away from or approaching one of the two poles of the main discourse (Tantoro, 2014).

Liberalist poverty discourse generally sees poverty as a condition created by the errors of behavior at the individual level, individual policy-makers, individuals experiencing poverty itself, or both; so poverty is considered a condition associated with individual mistakes in making planning choices, errors in economic direction, or errors in behavioral and mental aspects (Khomsan et al., 2015). Meanwhile, the discourse of socialist poverty sees poverty as a condition created by structural errors or a system that positions individuals in unequal relationships, where access to living resources is managed in such a way it benefits one party and disadvantages the other; consequently poverty is considered to reflect inequalities in the aspects of economic, social and cultural rights, civil and political rights, access rights to natural resources, and the right to access to empowerment, etc., (Sohibuddin \& Achmaliadi, 2010).

In the frame of the two mainstream discourses, the various meanings of poverty formulated by academics and theorists, resulting in various definitions, among others: poverty is a condition experienced by individuals or individuals living in a lower standard when compared with conditions of the surrounding community (Suparlan, 1984). Others see an inability to meet minimum living standards (Kuncoro, 1997); as deprivation of capability to grow (Sen, 2003); as a limited economic resources (Esmara, 1986); and as an inadequacy of income and wealth (Sallatang, 1986).Regardless of the various meanings of poverty as has been described it is necessary to remember, that poverty is a product of the dynamics of historical forces underway in specific historical material conditions (Sohibuddin \& Achmaliadi, 2010). Therefore, poverty has always been relative and linked to social definitions and experiences experienced by certain groups of people (Sen, 2003). Therefore, the understanding of poverty from the perspective of Southern Nias society requires an identification of the historical conditions in Southern Nias society, which has a stake in the construction and reconstruction of collective perceptions of poverty.

\section{B.ABOUT NIAS PEOPLES}

The origins of Nias people and their culture are still a mystery. There are various narratives that attempt to explain the genealogy of Nias inhabitants, where at least three main narratives are most commonly used in academic texts: versions of oral tradition; archaeological search version; and the latest is a molecular genetics version. In the oral tradition version, genealogy of Nias inhabitants is traced through hoho (Nias oral literature) interpreted in an interesting way. According to Hämmerle (2001) interpretation, it is assumed the people of Nias are the result of a blend of three types of people who inhabit Nias in three waves of arrival: the first wave was niha sebua gazuzu, a large-headed human group that 
inhabits the caves; the second wave was niha safusi, a white man who makes a settlement on a tree; and the last wave was lani ewöna, a group of people coming from overseas, who master advanced technologies like farming, metallurgy, architecture, and the art of warfare.

According to the archaeological version there is some archaeological and lingual evidence indicating that the ancestors of the Nias people were Austronesian language speakers who mastered the technology of making wooden sculptures, menhir monuments, and other megalithic objects; who migrated from the Yunan region in the mainland of southern China to Nias in waves since about 3500 years before Christ (Sonjaya, 2008). The latest developments are the findings of Mannis van Oven, of the Department of Forensic Molecular Biology, Erasmus MCUniversity Medical Center Rotterdam, which states the human DNA of Nias is similar to the natives of Taiwan Island and Philippine Islands, so that the ancestors of the Nias community probably came from the Austronesians who migrated from Taiwan via the Philippines route about 4000-5000 last year (Ovenet al., 2011).

Laiya (1980) found that the smallest social unit in Southern Nias society is called sangambatö or gagambatö, consisting of fathers, mothers, and children, but in the socio-economic context, the most important social unit is gagambatö sebua or extended family, consisting of people bound by blood relations and living together in a house; eat and cook in a shared kitchen; living from a common economic base; managing joint production assets, including agriculture, livestock, plantations, etc. It is this gagambatö sebua which is the main family unit in Southern Nias society, which consists of a family and the families of its children, which form a clan called mado or gana that serves as a boundary to determine who should marry whom; and then numerous mado or gana that settled in one region called banua or village (Laiya, 1980).

The Nias language belongs to the western branch of Malayo-Polynesian language in Austronesian languages (Brown, 2001). Although on a broader level it still has similarities to the language of communities around Nias Island, Nias language has some phonological and grammatical features that are not common to the surrounding areas (Brown, 2001). In addition, the Nias language is divided into three local dialects that mark the boundaries of the three main cultural regions on Nias Island, to say: North Nias, Central Nias, and South Nias (Hümmel \& Telaumbanua, 2007). Although there are however many types of cultural practices shared in these three areas, in the past the three regions are distinct, socially, linguistically, and politically (Hümmel \& Telaumbanua, 2007).

\section{C.The Concept of Poverty IN Nias Language}

In Foucauldian's discourse analysis, language is regarded as not merely reflecting reality but more than that, language is seen as a discursive structure that produces and displays reality in certain ways (Lawlor \& Nale, 2014). Here, discourses not only translate reality into language, but reconstruct reality and present it constitutively (Kelly, 2014). In other words, language is not just a reference for a person in perceiving reality, but is the main factor that shapes one's perception of himself and the world around him. Therefore, in the context of this paper, Nias language is a conceptual map that can be used to explain the meaning of poverty for the people of South Nias.

Poverty is of course something empirical. It is a real experience of a particular condition, as captured by the sensing instruments of the individuals who experienced it or witnessed it. But at a deeper level, poverty is not merely a sensory experience, but a conceptual experience constructed through the process of perception by using social material, the language and the cultural context. Language is a means for the expression of human experience (Kaelan, 2009), it is an instrument and medium used by humans to form knowledge of itself and the world around him (Barker, 2005). Consequently, without language the human experience of poverty can not be explained its meaning, because at the conceptual level of poverty is essentially just a form of abstract ideas hidden in the human mind, so without the expression of language he has little substance in reality.

According to Indonesian Dictionary (Pusat Bahasa Depdiknas, 2008), the word poor is translated as: no wealth; deprived or low income. While poverty is translated as: the poor; poor state; the situation of the population or part of the population that can only meet the food, clothing, and housing indispensable to maintain a minimum level of life. If we observe the meanings contained in the Indonesian Dictionary definition of poverty, then we can see that the definition is more inclined to the meanings of poverty centered on the economic elements alone, including income levels, production models, consumption patterns, ownership of assets, etc. In this case, Indonesian Dictionary does not offer any alternative meaning to poverty, as if in Indonesian culture the benchmark of human welfare level is only calculated on the accumulation of mere material objects. But is it so in Nias language? 
In Nias language, the word lumana or numana is used to refer to the general notion of poverty. According to the Nias language dictionary (Laiya et al., 1985), lumana is simply defined as poor. That is all. There is no additional explanation which describes the definition of poverty in a more specific way. In the framework of Foucault's theory, discourse is not a language in terms of grammatical or lexicon rules, but a practice of language composed of all statements ever made therein (Lawlor \& Nale, 2014). Therefore, to understand the meaning of the word lumana referred to in the Nias language dictionary, then we needs to review how the word is practiced in everyday use among the people of South Nias.

In five examples of the following words of Nias language (South dialect), the writer will demonstrate how the word lumana is used discursively: ya'ira niha si lumana(they are poor people); lumana drao ö be (you make me suffer); ma la sifa si lumana nia (his genitals were kicked); lumana sibai Inagu götö fa nebua ya'o (my mother raised me with great effort); lumana dödögu me mofanö fo'omogu (I grieve when my husband dies). In use of the word lumana as exemplified, it can be observed lumana is discursively used not only to reflect an economic condition when a person or a group of people lacks material possessions, but has a broader meaning that includes various aspects of suffering: pain, difficulty, sorrow, sadness, including poor due to lack of material possession. So in Nias language (Southern dialect), poverty in the sense of economic shortage is only one aspect of the meaning of the word lumana. Thus, it becomes difficult to reconcile the word lumana with the word poor in synonymous relation.

The Nias language is a symbolic language loaded with imagery, illustrations, and metaphors that there seems no relatively steady convention among the language users about the denotative meaning of a word (Hümmel \& Telaumbanua, 2007). Rather than pursuing on a certain sense, the word lumana actually offers various possible meanings, so the interpretation of the word lumana will be largely determined by situational codes or certain contexts that lead understanding to a certain meaning. But as a native language user of Southern dialect who actively practices it in everyday life, the writer believes the word lumana is more likely to be used to refer to a condition in which an individual or group of individuals experiences distress, sadness, or misery. The phrase lumana drao, Ina! (ouch, mother!) is a statement commonly said to express, pain, distress, suffering-say after a knocked shin bone. While in the Indonesian language, would be awkward if someone expresses pain when his shin bones get hit, with the word miskin or poor. In this case, poverty in the sense of economic shortage is only one of the meanings of the word lumana it is also because the economically deprived is synonymous with distress and misery.

Czarniawska (2004) found that it is impossible to understand human behavior when ignore the goals it contains; and it is impossible to understand these goals if ignore the background (the context) that makes them understandable. Therefore, in an attempt to confirm the writer's allegation of the meaning of the word lumana, the writer tries to reflect on certain socio-cultural contexts related to the formation of the meaning of the word lumana. Here, the writer tries to observe some social practices among the people of South Nias, rooted in the historical-material conditions experienced by the people of South Nias in the past. In addition to language, history also occupies a privileged position in Foucault's theory of discourse. As a historical observer, Foucault is deeply interested in how historical processes construct discourse (Mills, 1997). According to Foucault, the past plays an important role in the formation of contemporary meanings (Lawlor \& Nale, 2014), so in explaining the practices, representations, languages, and practices prevailing in today's Southern Nias society, we need to ponder past conditions critically.

\section{D.SOUTH NiAs CULTURE}

The earliest documentation of the Nias tribe was found in the note of a Middle Eastern merchant named Sulayman circa 851; followed by a record of the island of Nias in the Book of Magical Al-Hind circa 950; next note written by a merchant from Ceuta named Edrisi circa 1154; record traders from Azerbaijan called Kazwini circa 1260; records of the islands of Al-Binaman and Al-Banan (Nias islands) written by a Syrian trader named Ibn Al Wardi around 1340 (Härmmerle, 2001); and since then the mystery of the tribe of Nias and its megalithic culture has increasingly attracted the interest of scientists, from colonial times to the present. From the initial notes on Nias summarized in Hämmerle's book, the writer sees that there is one common point that always mentioned in the records, namely tribalism expressed through head hunting, slavery and tribal war, especially among Niassan tribal groups who live in the South Coast of Nias Island.

For the people of South Nias in the past, head-hunting, slavery, and tribal war were a product of historical conditions that was given, in 
which one must live it without being able to choose to accept or reject. Consequently almost all the cultural expressions of the people of South Nias are dedicated to survival and adaptation to these threatening environmental conditions. Scarduelli (1990) said that all aspects of the arrangement of communal life in South Nias, ranging from the management of everyday life, settlement development, to raising offspring, all intended for efforts to defend against attacks. The village is built on hilltops and protected by two to three layers of fortresses with deep trenches whose base is planted with pointed bamboo; its gates are heavily guarded and sealed at night; sentries are always around and women are always guarded by armed warrior, even when just about to take water in the shower (Scarduelli, 1990).

War of course destructive and bring misery. But in the context of academic studies it is too naive to deny the productive aspects contributed by tribal war to Southern Nias culture. Here, the writers estimate there are at least three aspects of tribal wars that contribute to the cultural development of the people of South Nias. First, war naturally maintains the composition of the population so that the human population remains in a range that can be tolerated by carrying capacity of the natural environment of Nias Island, which certainly has a threshold. Second, war is an adhesive agent for social cohesion within communities in each village, by forcing them to dampen internal conflicts, maintain social integration, to focus on efforts to confront common enemies coming from outside. Third, war provides a stimulus for creative endeavors to sustain life through technological innovations and socio-political organizations.

The first estimate that the writers propose would still require proof and further research before it can be concluded. The second and third estimates, however, appear to have gained a theoretical grounding in the findings of earlier researchers, indicating that the threat posed by war, slavery and head hunting has prompted each village in South Nias to expand its socialpolitical linkage network, to the extent of the social relations between individuals living in one village, becoming broader political alliances with neighboring villages, through a traditional sociopolitical organization called öri, which is a sociopolitical organization formed by a number of villages, each bound by the kinship ties built through the myth of genealogical similarity and marital relationships among its inhabitant (Suzuki, 1959). The magnificence of South Nias civilization artifacts whose form can still be witnessed today is closely related to the existence of öri, which is characterized by strong political alliances between lineages (clans); complicated traditional party cycles; as well as rigid social stratification (Lansing and deVet, 1990).

Öri is an adaptation strategy for the people of South Nias to survive in the midst of a crisis caused by the threat of war, slavery, and head hunting going on for hundreds of years. Here, öri is a local wisdom exclusively existing in South Nias, before it eventually spread throughout Nias through the intervention of the Dutch colonial government, which introduced the concept of the alliance to other villages outside South Nias (Lansing and deVet, 1990). Political alliances between villages in South Nias are not only aimed at defending against outside attacks, but also as a basis for mutual agreement not to hunt heads among fellow members of the öri, so that the social energy of the people of South Nias who previously consumed for battle can be projected for more productive activities, including: farming, raising, developing village infrastructure, and creating art forms (Lansing and deVet, 1990). With the formation of öri, each village in South Nias could eventually develop, and be inhabited by thousands of inhabitants living together in an area approaching the complexity of a city (Lansing and deVet, 1990).

\section{E.SOCIAL EXCHANGE PRACTICES}

The inter-village alliances institutionalized in öri are essentially a sacred pledge, legitimated and preserved through a series of rituals involving the practice of human head offering (binu), the establishment of stone menhirs (fanaru'o batu), and the swearing of the oath (fondrakhö) (Lansing and deVet, 1990). The institutionalization process is traditionally organized with reference to a complex set of complex protocols, and is celebrated in a crossvillage feast of merit cycle called owasa (Scarduelli, 1990). Without owasa the alliances institutionalized in öri have no legitimacy and have no binding power. The complexity of the customary protocols in the feast of the owasa, symbolically represents the individual and collective claims of who should be subject to whom; who can marry whom; which in its substance is a ritual to define one's identity, status, and social role in society (Beatty, 1991). But behind all these complexities, the writer considers the ideology represented in the owasa is simple: that the social relationships between individuals in the society of South Nias are fundamentally expressed through the practice of giving and receiving, which in 
sociology/anthropology theory is called social exchange.

Social exchange is a social principle that essentially states every social relationship is always influenced by the expectation of reward, profit, and sacrifice (Levi-Strauss, 1969). That is, a social relationship will only go well when each involved party is aware of the benefits or rewards that can be gained through the relationship. In the context of this theory, group integration and solidarity among the people of South Nias also involves the principle of social exchange, as is often stated in the proverb: haya khöu khögu, which literally means what gains or rewards I will get from you. Thus, owasa can be seen as a social institution that traditionally provides space for the people of South Nias to engage in social exchanges so as to construct and reconstruct social cohesion among them, through the practice of sharing food and resources (gold, livestock, labor, etc.) .

The cultural roots of the social exchange system in Southern Nias society can be traced to the traditional belief system of the people of South Nias itself. Spiritually Nias people believe everything in the universe has its owner or its ruler. The rice owner in the fields is a spiritual entity called Sibaya Wakhe; the pig owner on the farm is called Sobawi; the owner of wild pigs in the forest called Bela; the owner of fish in rivers called Tuha Zangararöfa (Hümmel \& Telaumbanua, 2007). Consequently production activities, like farming, raising, hunting, fishing, etc., always involve spiritual elements and rituals aimed at asking for something to their owners. In South Nias culture, asking is not just a one-way practice, but is reciprocal, meaning to ask for something then an individual must also give, which here is manifested in an offering to a spiritual entity regarded as the owner of the things requested, either before or after being given. Violations of the reciprocal principle will have a negative impact on production activities, including: harvest failure, livestock disease, game becoming scarce, etc., (Hümmel \& Telaumbanua, 2007).

The principle of giving and receiving is the ideological basis for the implementation of the owasa. Here, the owasa is not only practiced on communal initiative, but also individual initiative: each individual is traditionally required to actualize himself through a series of owasa levels, which represent important events in a person's life cycle, from birth to death (Beatty, 1991). In the writer's experience as a member of the South Nias community, the term owasa tends to represent a colossal, cross-village celebration, involving mass participants, and organized on communal initiatives; while to refer to a relatively simpler type of celebration held on personal initiative, people usually choose to use the term tawila. In principle both have the same understanding, as a ritual to invoke the blessings of the ancestral spirits and the social recognition of fellow members of society. But at a more subtle level owasa or tawila is a means to showcase social competence so as to increase the status, prestige, and social influence of a person in society (Laiya, 1980).

As a social being, one's existence is not only determined by personal awareness of his identity, but also involves the recognition of others around him, so that personal claims of identity, status, and role gain legitimacy and become socially legitimate (Kellner, 2010). In the Southern Nias society, the social recognition of one's self-existence is primarily obtained through owasa or tawila The ability to organize owasa or tawila is an indicator that proves that a person has a quality that is socially demanded by the people of South Nias, namely: fa'onekhe or cleverness; fa'atani or courage; mokhö or economic power; where when one succeeds in organizing owasa or tawila, then society will recognize the next quality, ie fa'asia'a or seniority as well as lakhömi or glory (Laiya, 1980).

In short, the social obligation to administer owasa or tawila is something demanded by society, in order for one to be socially recognized as a human being of complete quality (Laiya, 1980). Here, there are six levels of tawila that must be carried out by individuals who come from among the common people or sato; and of these six levels, an individual should at least carry two levels in his lifetime, namely tawila for his marriage and for the death rites of his parents (Scarduelli, 1990). While for individuals of noble descent, in addition to these six levels, there are another six levels of tawila or owasa that must be followed next, each level will be larger and more expensive than the previous level (Lansing and deVet, 1990). So it is conceivable how much it would cost a member of the Nias community to mobilize toward the top of the self-actualization hierarchy. Only individuals with very special circumstances are exempted from this obligation (Beatty, 1991), for example: a person who is unable to work from physical disability, orphan or someone without relatives, widows, and slaves. These are what are traditionally called the poor.

\section{F.DISTRIBUTION OF WEALTH}

The writers have explained the cost of conducting a tawila course is expensive, since the 
magnitude of the need for each level has been determined collectively through the fondrakhö ceremony (Lansing and deVet, 1990) and documented in the customary form called böwö (Laiya, 1980). What is interesting, however, is that the cost is not borne alone by the organizers of tawila, but is collectively covered with the support of all the relatives of the tawila organizers. Each relative is obliged to assist in the amount determined by the proximity of blood relation and status in the hierarchy of custom relations which relates to the position of each family group, whether as a wife giver or wife taker (Lansing and deVet, 1990). In addition to support from relatives, tawila organizers also gained support from fellow villagers on a scale that depends on the status, prestige, and social influence that individual tawila organizers have. The higher a person's social position the wider the support network will be.

It should be underlined in this assistance that the assistance provided by relatives and fellow villagers to tawila organizers is not a voluntary free grant, rather a customary debt whose numbers will be remembered either by the aid provider or beneficiary (Scarduelli, 1990). Assistance given by the aid provider can be of various kinds, which may be one or a combination of the following: gold (now money), groceries, or when one does not have any material to offer, then at the least level the individual will offer his strength (Beatty, 1991). Although many traditional terms are used to refine these debt relations, debt is debt and certainly must be paid. There is no interest in this indigenous debt system, so it will be repaid in a value at least the same (Beatty, 1991). But according to the writer's experience, if paid a little larger, it will be appreciated and considered an expression of closeness in kinship. Here, debt is not something that has a negative connotation in South Nias culture, instead it reflects the social ties as the writers have described in the discussion of social exchange.

When the tawila is celebrated the individual organizer of the tawila will give a gift called urakha to the guests attending the party. Urakha can be gold (money), live cattle, or foodstuff, depending on whom the urakha is given (Beatty, 1991). The higher the social status of the guest who receives urakha, the more valuable the type of urakha is given. The interesting thing here is the urakha given by the tawila organizers to the guests is also not a free gift, but is a customary debt that will eventually be paid (Beatty, 1991). So the position of the organizer tawila which originally was the debtor to the parties, who have helped, now turned into a creditor to the guests who invited. According to the writer's experience, refusing an invitation to attend tawila is a rare occurrence, because if $\mathrm{A}$ refuse to attend the tawila held by $\mathrm{B}$; then in time $\mathrm{B}$ will also refuse present at the tawila held by A. So that social bond in Southern Nias society is intertwined in complicated customary debt networks, where one with another receives and gives debt for the rest of his life. This customary debt is the basis for social integration in Southern Nias society. Collective memory of the aid received or given to fellow members of the community is the reason for the traditional solidarity among fellow citizens.

Due to the social pressure to organize owasa or tawila among the people of South Nias in the past, none of the members of society can escape the need for debt. The standard of customary cost set forth in the böwö rules is high so even a rich nobleman may inevitably have to be in debt if he wants to carry out the owasa. Conversely, no one intends to escape the obligation to pay customary debt. There are several reasons for Beatty's (1991) explanation: moral reasons, where customary debt is not just personal debt but the debt of the whole family, so that when one refuses to pay the customary debt it will undermine the integrity of himself and his whole family; economic reason, that is, when an individual refuses to pay his customary debt means that the individual is closing the opportunity to obtain assistance when experiencing future difficulties; and spiritual reasons, where the people of South Nias strongly believe that when an individual refuses to pay his customary debt he will get a curse that makes him misfortune, get accident, or fall ill.

The customary debt relation in Southern Nias society is not only limited to the implementation of the owasa or tawila, but to seep into every joint of social, economic, and political life of the people of South Nias. For example, as Hümmel and Telaumbanua (2007) illustrates the practice of falulusa, an agricultural pattern in which today a group of people work together to work on A's land, tomorrow they will work together to work on land belonging to $B$, and so on until all the land belongs to members of the group can be worked on. In the logic of customary debt, this makes significant sense because when someone else is involved in working on A's land then A becomes a debtor and must pay his debts by being involved in contributing to the construction of B's land, and so on. In this form of cooperation, insufficient resources experienced by one group member, like shortage of work tools, shortage of seeds, shortage of labor, etc., will be covered by debt to 
the group members, which will be paid at harvest.

Prior to the arrival of the Dutch colonial to Nias, the accumulation of economic surplus in material possessions, as is common in traders' societies, is a rarity among the people of Nias. Trade practice in limited quantity is only done by Nias people with professional traders who come from outside Nias, for example with Chinese traders, Aceh, or Minang, while trade practices among fellow Nias are rare (Hümmel \& Telaumbanua, 2007). In addition, South Nias people in particular prefer to invest the economic surplus they have earned on activities to mobilize the accumulation of social capital, through the implementation of owasa and tawila, since the economic surplus invested in accumulated assets has the potential to create jealousy social and threatening social integration (Scarduelli, 1990). Consequently, the wealth of an individual in the Southern Nias society is more often expressed in symbolic form, for example in menhir monuments, skulls and jaws of pigs that hang in the house. It is a marker for numbers of owasa and tawila ever held, as well as to mark the level of status, role, and extent of social influence networks owned by a person.

\section{G.DisCOURSE CLASH}

Thus, in the context of the principle of social exchange and the distribution of resources practiced by traditional South Nias societies, customary debt relations have formed a type of social safety net that makes poverty holes patched by social integration and traditional solidarity. So that poverty in the sense of insufficient material possessions to live a decent life is unsuited to explain the condition of the traditional South Nias community, because traditionally the prosperity indicator in Southern Nias society is not the accumulation of material capital rather the accumulation of social capital. Traditionally, what a member of the South Nias community needs to live decent is a good social relation with other individuals around him, as is often expressed in the proverbial Nias South, gaö so harato sebua ba fa'asara dödö which means the greatest treasure lies in a union.

The tendency of traditional South Nias people to be more motivated to accumulate social capital rather than material capital, makes the pattern of economic behavior to be relatively different when compared with the economic behavior patterns of other community groups around them. From the perspective of modern economic discourse held by the majority of people outside of Nias, the traditional economic behavior of the people of South Nias is unusual, so it tends to be approached with prejudice and suspicion. Here, the power operating through discourse has an almost compulsive obsession with control. Control is the most obvious expression of power; anything out of control is always a threat and draws the attention of moral, legal, and aesthetic powers to discipline it (Mills, 1997). The traditional culture of South Nias along with all the positive and negative aspects embedded in it, is considered a form of deviation that needs to be disciplined. Consequently, since the colonial era, the people of South Nias have become the disciplinary objects of various cultural forces, either by means of arms and violence; or by using more subtle power in formal institutions, including: religion, government programs, schools, etc.

There are at least three major moments in the historical timeline of South Nias, where the power of history has brought about a major shift in the culture of the people of South Nias. First, it is the arrival of Christian evangelists who overturned almost all the traditional views of Southern Nias society on the world. Unilaterally the evangelists claim to represent God's authority to ban the people of South Nias from practicing most of their culture. Various practices in everyday life, including paganism, head hunting, celebrating owasa, tribal war, are suddenly considered something barbaric and sinful (Hümmel \& Telaumbanua, 2007). No more loin-clothed men and bare-chested women, it has become an embarrassing past and must be covered with factory-made fabrics. The whites set new standards and prohibit head-hunting, slavery, warfare, and the practices of the owasa and tawila, which make the traditional bonds established through these cultural practices, also disappear. The nobleman lost the basis for the legitimacy of their power, while the commoners lost a unifying symbol. The prohibition to organize owasa makes social pressure to keep owasa and tawila reduced, which means the need for debt is also reduced. As a result, the social safety network built through the customary debt system is disrupted.

Second, is the entry of the New Order government system and its development ideology. The New Order government replaced the concept of banua with the concept of desa or village. In the New Order development ideology, the village is considered a subaltern that occupies a more inferior position than the city, as seen from urban control over the village, which during the Soeharto era was expressed through the direction of development resources flowing from national to provincial, district, sub-district, etc., (Agusta, 2014). In the case of South Nias, the 
flow of development resources from the central government to the village increased the village's dependence on the government, as well as undermining village self-sufficiency in meeting the needs previously pursued independently. The word aid has a new meaning, which no longer refers to the customary debt support obtained from relatives and is to be repaid; but a free gift from the state for its poor and disadvantaged citizens. Conversely, poverty also gains new connotations that no longer refer to people who lack social capital, but as bargaining positions that allow an individual to get help from the government.

Third, are the post-tsunami relief project 2004 and the 2005 earthquake that brought hundreds of analysts, consultants, specialists from overseas into South Nias. They brought together various poverty theories and concepts that became the reference for various disaster management and community empowerment policies, held on Nias Island under the coordination of the Rehabilitation and Reconstruction Agency (BRR) for Aceh and Nias. As one of the UNESCO staff stationed in South Nias in the post-tsunami period of 2004 and the 2005 earthquake, the writers witnessed and experienced for themselves how the people of South Nias competed to claim themselves as poor, thereby becoming eligible to receive assistance from the government or donor agencies. Meanwhile, some people of South Nias who are keen enough to take economic opportunity in the momentum of the postdisaster relief flow have accumulated significant economic capital and seized the position of a new elite class in Southern Nias society. This aborts the traditional agreements on social mobility and social stratification. The post-tsunami relief project 2004 and the 2005 earthquake have established new standards of prosperity, identity, status, and roles; as well as outlining new measures of poverty.

These three historical moments alternately construct various aspects of South Nias culture, as well as reconstruct the collective ways of Southern Nias society in seeing themselves and the world around them. These three moments offer new discourses as a guide for action and behavior in response to the environment in an effort to meet the needs of life. In the context of this new discourse, the notion of poverty originally refers to the condition of the lack of social resources to participate in social activities; now refers to the condition of the lack of economic resources to participate in market activities. Poor which was originally a social discourse; is now an economic discourse. Money and consumption practices are a new measure to characterize prosperity and self-actualization. So that wealth is no longer expressed through symbolic objects that mark the accumulation of social capital, like: pig jaw and menhir monument; rather through symbolic objects that mark the accumulation of economic capital, like cars or concrete houses.

In this new discourse, some members of the community of South Nias who were not classified as poor are now poor, including farmers and fishermen. Originally farmers and fishermen working for food, they are now working to earn money. When calculated on the basis of feeding needs, the products of the farmers and fishermen is more than enough to meet the needs of their family; but when the production is calculated on the market value or money value, what is produced by the peasants and fishermen of traditional South Nias becomes less. This lack of money is the root of poverty in South Nias. Despite having enough food and shelter, the lack of money makes the farmers and fishermen of South Nias believe they are poor. The belief is increasingly justified in various official government policies, including: the determination of the status of South Nias as Disadvantaged Areas through the issuance of Presidential Regulation No. 131 of 2015 on the Determination of Disadvantaged Regions 2015 2019 signed by President Jokowi on 4 November 2015.

\section{CONCLUSION}

Controlling the meaning of poverty is a strategic goal in the ideology of development. Anyone who succeeds in seizing authority to define poverty will automatically grasp the control of the meaning of poverty, and seize the right to exploit those meanings for his own purposes (Agusta, 2014). In fact, there are many parties concerned with the definition of poverty: government, non-governmental organizations, private corporations, banks, investors, and of course the poor themselves. All these social units have their own reasons for seizing authority to define the meaning of poverty. Consequently, the authority to define poverty becomes something negotiated and contested. The will to control the meaning of poverty, cultivate various techniques of determining and calculating methodology of the number of poor people, each of which competes to be the most standard determining and measuring system (Agusta, 2014). But among the various social forces fighting for authority in determining the meaning of poverty, is there a force that represents the interests of the poor themselves? 
From the descriptions the writer has pointed out, we can observe that in the case of poverty in South Nias, poverty is a concept whose meanings are temporary, fluid, and contingent. The meaning of poverty among the people of South Nias can be said to be the effect of certain discourse operations that affect the way a group of people perceive themselves and the world around them. In this case, poverty is a social perception held collectively by a group of people, which leads members of that society to a certain world view to the world, which makes them feel deprived. In other words, culture plays a central role in the case of poverty in South Nias. This confirms the importance of further studies in the field of culture to support poverty alleviation programs, since poverty does not only infect the body but also infect the mind.

Culture is an experience in everyday life; it is various texts, practices, and meanings that are lived not in a self-created field, but under conditions that are simply given (Barker, 2005). Here, living in a post-modern world is a given condition for the people of South Nias. Without being given the opportunity to transition into modern society, traditional communities in South Nias are forced to deal with advanced capitalism. The people of South Nias seem to have been forcibly taken from their lives in the past, and then put into a time machine, and when the door of the machine is open they suddenly have to deal with the current world. The changes that have made the various life forms, values, and identities of the past seem obsolete, vain, or no longer socially valid, while new life forms, values, and identities offered in the post-modern world are still within the process of coagulation and still take a long time before it becomes relatively stable to adhere to. This condition makes some people of South Nias experience social anxiety, feeling giddy due to loss of orientation and confusion of identity.

The only option for the people of South Nias today is to prepare a cultural strategy based on their tradition along with new innovations built on it, to respond to the influence of external cultures that unilaterally claim superior positions and try to dictate their values, norms and tastes. This cultural strategy opens opportunities for the peoples of South Nias to be not only the object of discourse battles, but to be subjects who take part in the contestation. But this cultural strategy is only possible if the traditional cultural institutions that exist in society re-consolidate relationships among them, as well as redefine the rules of the game in social interaction and social exchange, in an effort to reassemble the network of traditional social alliances of South Nias. Alliances like in the past are still needed because the war is still going on, and this time takes space in the realm of culture, where each cultural discourse fights over each other for domination over human thought and will. The important agenda for the people of South Nias in this battle of discourse is to reclaim the rights to self-definition, to identify their own needs, and to live a life measured by standards and indicators stemming from the perspective of society itself in seeing itself.

\section{REFERENCES}

Agusta, I. (2014). Diskursus Kekuasaan dan Praktik Kemiskinan di Pedesaan. Jakarta: Yayasan Pustaka Obor Indonesia.

Badan Pusat Statistik Sumatra Utara. (2016). Sumatra Utara Dalam Angka 2016. Medan: CV New Creative.

Barker, C. (2004). The Sage Dictionary of Cultural Studies. California: Sage Publication.

Barker, C. (2005). Cutural Studies Teori dan Praktek. Penerjemah: Tim KUNCI Cultural Studies Center.Yogyakarta: Bentang Pustaka.

Beatty, A. (1991). Owasa: Feasts of Merit in Nias.

Bijdragen tot de Tall-, Land- en

Volkenkunde,Deel147, 2/3de Afl., pp. 216-235

Bloomer, C.M. (1990). Principles of Visual Perception. Great Britain: The Herbert Press.

Brown, L. A. (2001). Grammar of Nias Selatan. (Doctoral Thesis). University of Sidney, Australia.

Czarniawska, B. (2004). Narratives in Social Science Research. London: SAGE

Publications Ltd.

Danesi, M. (2010). Pesan, Tanda, dan Makna. Buku Teks Dasar Mengenai Semiotika dan Teori Komunikasi. Penerjemah: Evi Setyarini dan Lusi Lian Piantari. Yogyakarta: Jalasutra. 
Esmara, H. (1986). Perencanaan dan

Pembangunan di Indonesia. Jakarta:

Gramedia Pustaka Utama.

Fiske, J. (2010). Cultural and Communication Studies. Sebuah Pengantar Paling Komprehensif. Penerjemah: Idi Subandy Ibrahim dan Yosal Iriantara. Yogyakarta: Jalasutra.

Gray, A. (2003). Research Practice for Cultural Studies. Amazon Kindle Edition.

Hartley, J. (2010). Communication, Cultural, and Media Studies: Konsep Kunci. Penerjemah: Kartika Wijayanti. Yogyakarta: Jalasutra.

Härmmerle, J. (2001). Asal-usul Masyarakat Nias: Suatu Interpretasi. Gunung Sitoli: Yayasan Pusaka Nias.

Hümmel, U., Telaumbanua, T. (2007). Cross and Adu: A Socio-Historical Studies on The Encounter Between Christianity and Indigenous Culture on Nias and The Batu Islands 1865-1965. (Doctoral Thesis) University of Utrecht.

Kaelan. (2009). Filsafat Bahasa, Semiotika dan Hermeneutika. Yogyakarta: Paradigma.

Kelly, M.G.E. (2014). Foucault And Politics. Ediburgh: Ediburgh University Press.

Kellner, D. (2010). Budaya Media. Cultural Studies, Identitas, dan Politik: Antara Modern dan Postmodern. Penerjemah: Galih Bondan Rambatan. Yogyakarta: Jalasutra.

Khomsan, A., Dharmawan, A. H.,Saharuddin, Alfiasari, Sukandar, D., Syarief, H. (2015). Indikator Kemiskinan dan Misklasifikasi Orang Miskin. Jakarta: Yayasan Pustaka Obor Indonesia.

Kuncoro, M. (1997). Ekonomi Pembangunan. Yogyakarta: UPP AMP YKPN.

Laiya, B. (1980). Solidaritas Kekeluargaan Dalam Salah Satu Masyarakat Desa di Nias-
Indonesia. Yogyakarta: Gajah Mada University Press.

Laiya, S.Z., Zagoto, S., Laiya, H., Zagoto, S., Zagoto, A. (1985). Kamus Nias - Indonesia. Jakarta: Pusat Pembinaan dan Pengembangan Bahasa Depatemen Pendidikan dan Kebudayaan.

Lansing, J.S., deVet, T.A. (1990). Head-hunting, Chieftainship and Alliance in Southern Nias. in Structuralism'sTransformations: Order and Revisions in Indonesian and Malay Society. (eds.) Lorrain Aragon and Susan Russel. Tempe, AZ Program for Southeast Asian Studies, Arizona State University, pp. 69-91.

Levi-Strauss, C. (1969). The Elementary Structures of Kinship. Boston: Beacon Press.

Lawlor, L., Nale, J. (2014). The Cambridge Foucault Lexicon. Pennsylvania: Cambridge University Press.

Mills, S. (1997). Discourses. London and New York: Routledge.

Mills, S. (2003). Michel Foucault. London and New York: Routledge.

Oven, M. van, Hämmerle, J.M., Schoor, M. van, Kushnik, G., Pennekamp, P., Zega, I., Lao, O., Brown, L. Kennerknecht, I., Kaiser, M. (2011). Unexpected Island Effects at an Extreme: Reduced Y-Chromosome and Mitochondrial DNA Diversity in Nias. Molecular Biology and Evolution 28: 1349-61.

Pusat Bahasa Depdiknas. (2008). Kamus Besar Bahasa Indonesia (Edisi ke-4). Jakarta: Gramedia Pustaka Utama.

Rohidi, T. R. (2000). Ekspresi Seni Orang Miskin: Adaptasi Simbolik Terhadap Kemiskinan. Bandung: Penerbit Nuansa.

Sallatang, M.A. (1986). Kemiskinan dan Mobilisasi Pembangunan. Makalah, Ujung Pandang: Lembaga Penerbitan UNHAS. 
Scarduelli, P. (1990). Accumulations of Head,

Distribution of Food: The Image of Power

in Nias. Bijdragen tot de Tall-, Land- en

Volkenkunde,Deel 146, 4d afl., pp 448-

462.

Schiffman, L., dan Kanuk, L. L. (2008). Perilaku Konsumen.Penerjemah: Zoelkifli Kasip. Jakarta: PT. Indeks.

Sen, A. (2003). Poverty and Famine: An Essay on Entitle and Deprivation. England: Oxford University Press.

Sohibuddin dan R. Achmaliadi (Eds.). (2010). Memahami Dimensi-Dimensi Kemiskinan Masyarakat Adat. Aliansi Masyarakat Adat (AMAN).

Sonjaya, J.A. (2008). Melacak Batu, Menguak Mitos: Petualangan Antar Budaya di Nias. Jakarta: Penerbit Kanisius.

Suparlan, P. (1984). Kemiskinan di Perkotaan. Jakarta: Yayasan Pustaka Obor Indonesia.

Suzuki, P. (1959). The Religious System and Culture of Nias, Indonesia. Michigan: Uitgeverij Excelsior.

Tantoro, S. (2014). Pembasmian Kemiskinan: Perspektif Sosiologi-Antropologi. Yogyakarta: Pustaka Pelajar. 